\title{
The Effects of Arbitrator's Lack of Impartiality and Independence on the Arbitration Proceedings and the Task of Arbitrators under the UNCITRAL Model Law
}

\author{
Ahmed Mohammad Al-Hawamdeh ${ }^{1}$, Noor Akief Dabbas ${ }^{2} \&$ Qais Enaizan Al-Sharariri ${ }^{3}$ \\ ${ }^{1}$ Jerash University, Jordan \\ ${ }^{2}$ Amman Arab University, Jordan \\ ${ }^{3}$ Irbid National University, Jordan \\ Correspondence: Ahmed Mohammad Al-Hawamdeh, Jerash University, Jordan. E-mail: \\ ahmedalhawamdeh@hotmail.com
}

Received: May 22, 2018

doi:10.5539/jpl.v11n3p64
Accepted: June 27, $2018 \quad$ Online Published: August 30, 2018

URL: https://doi.org/10.5539/jpl.v11n3p64

\begin{abstract}
This paper aims to investigate the effect of arbitrators' lack of impartiality or independence on the arbitration process in accordance with the Model Law. The reasons for choosing the latter is that it is the origin for most modern national arbitration laws and any amendments to it would likely to be followed by national laws. The research problem lies in the fact that the Model Law does not tackle in detail the issue of challenging arbitrators for lacking impartiality or independence. A challenge application would have an immediate effect on both the arbitration proceedings and the task of arbitrators. This study concludes that grounds for challenging arbitrators' impartiality or independence under the Model Law are broad and general. Hence, regulating the scope, grounds and limitations related to the lack of impartiality or independence on the part of arbitrators should be addressed in depth in the Model Law to safeguard the interests of arbitration parties and therefore justice at large.
\end{abstract}

Keywords: arbitrator impartiality, arbitrator independence, arbitrator's challenge application, the Uncitral Model Law on International Commercial Arbitration

\section{Introduction}

Impartiality and independence of arbitrators are considerable safeguards for the parties of a dispute and all those directly connected to it. ${ }^{1}$ Impartiality and independence of arbitrators are also important in ensuring confidence in the integrity not only of the arbitral process, but also the whole arbitration establishment. In other words the impartiality and independence of arbitrators are important to promote litigants' trust in the arbitral process. Hence, most national and international arbitration laws confirm that it is the duty of arbitrators to be and remain impartial and independent throughout the arbitration process. Otherwise, arbitration laws provide parties of an arbitration with the right to challenge any arbitrator. For example, Article 12/2 of the Uncitral Model Law on International Commercial Arbitration 1985 as amended (Model Law, therefrom) establishes: 'An arbitrator may be challenged only if circumstances exist that give rise to justifiable doubts as to his impartiality or independence...'. If a challenge application is successful, the arbitrator will be removed and consequently replaced in accordance with the rules governing the arbitration proceedings. The question here lies in what the rules that govern the impartiality and independence of an arbitrator are, and the effects of lacking impartiality or independence on the arbitration process and the arbitral tribunal have.

In carrying out an arbitration assignment, an arbitrator may take action in good faith that affects impartiality or independence, as well as potentially coming across a situation where impartiality or independence are negatively affected due to reasons out of the arbitrator's control. Furthermore, the arbitrator might have had relations with either party of the arbitration prior to the commencement of an arbitration task. This might possibly lead to the arbitrator being challenged by either party of the dispute, which in turn may result in the annulment of the arbitral proceedings that the challenged arbitrator has taken part in. Eventually, the same effect applies to the

\footnotetext{
${ }^{1}$ Koch, Christopher, (2003). Standards and Procedures for Disqualifying Arbitrators. Journal of International Arbitration. Vol. 20, No 4, p. 325.
} 
arbitral tribunal whether it consists of one or multiple arbitrators.

International and national arbitration rules do not clearly define the standards for the impartiality and independence of arbitrators. The Model Law is not an exception to this. Since the Model Law is considered to be the source in legislating most modern national arbitration laws, it is rather important to dwell on the principles of applying for challenging arbitrators' lack of impartiality and independence in accordance with the Model Law. This paper is divided into three main sections (2,3 and 4); the next section; section 2; focuses on the scope of the application of impartiality and independence in arbitration. The third section concentrates on the effects of lacking impartiality and independence on arbitral proceedings. The fourth section tackles the effect of a lack of impartiality and independence on arbitral tribunals.

\section{Scope of Application of Impartiality and Independence in Arbitration}

Although the concepts of impartiality and independence co-associate ${ }^{2}$ in most arbitration legislations, they are still different to the extent that each has its own rules and principles. ${ }^{3}$ There are various legal standards on which arbitrators' independence and impartiality are based. The English jurisdiction for example uses 'the real danger of bias standard'. The American jurisdiction on the other hand uses the standard of 'an arbitrator not only has to be impartial but also appear to be impartial'. However, the Model Law uses the 'justifiable doubts' standard, which has been adopted by several jurisdictions. The latter standard is the base for this paper.

Partiality is different from dependence in the sense that the concept for the former is subjective, while the concept for the latter is objective. ${ }^{4}$ The mere concept of partiality is related to the state of mind that can only be proved through facts, measured by external conduct. ${ }^{5}$ Being an abstract subjective concept, makes it exceptionally difficult to be measured and therefore proved. Hence, the Model Law does not require proving actual partiality. It rather requires proving 'justifiable doubts' as for an arbitrator lacking partiality. Hence, impartiality in relation to arbitrators is the absence of 'justifiable doubts' in an arbitrator's state of mind for being bias, in favor of, or prejudiced against, a particular party of the dispute. ${ }^{6}$ Independence on the other hand, could be defined as the absence of any relationship, whether personal, social or financial, between the arbitrator and a party of the arbitration. ${ }^{7}$ Despite the fact that the Model Law relate 'justifiable doubts ${ }^{8}$ to both impartiality and independence, for the latter being an objective concept, 'justifiable doubts' does not play a major role in proving it. This is because proving the existence of a relationship between the arbitrator and any of the arbitration parties should not be difficult. In most case scenarios whenever an arbitrator encounters a lack of independence, they would in turn, encounter a lack of impartiality for hearing the dispute. ${ }^{9}$

Partiality may also arise under the arbitrator's wide discretionary powers which are normally related to his or her personal knowledge and experience. This is of course provided that such wide discretionary powers are

\footnotetext{
${ }^{2}$ Alan Redfern and Martin Hunter in their book, Law and Practice of International commercial arbitration (4th ed. 2004, p. 201), noted that there is a point of view in considering the two terms as being the 'opposite side of the same coin.' Independence on one side refers to the arbitrator's relationship with one of the parties; impartiality, on the other side, 'is considered to be connected with actual or apparent bias of an arbitrator either in favour of one of the parties or in relation to the issues in dispute.' The two terms are 'usually joined together as a term of art.'

${ }^{3}$ However, the ICC takes a different point of view, including only the sole test of independence. The ICC justification to this is that independence is an objective test that should be viewed in a broad sense to include the concept of impartiality. See, Hascher, Dominique, ICC Practice in Relation to the Appointment, Confirmation and Replacement of Arbitrators' (ICC International Court of Arbitration Bulletin, Volume 6 No. 2, November 1995) at p. 6.

${ }^{4}$ Al-Nimer, Abu-Al-Ola (without a year of publication). Constitution of Tribunals. $1^{\text {st }}$ Edition. Cairo: Al Nahdah Al Arabiyya House. P. 52.

${ }^{5}$ Abdul-Rahman, Huda M. (1997). Arbitrator's Role in Disputes. Cairo: Al Nahdah Al Arabiyya House. p. 85.

${ }^{6}$ Blackaby, N., and Partasides, C., with Redfern, A., and Hunter, M., Redfern and Hunter on International Arbitration (5th ed) (Oxford, United Kingdom; Oxford University Press, 2009), p. 267. Constantine Partasides, The Selection, Appointment and Challenge of Arbitrators, 5 VINDOBONA J. 217, 217 (2001).

${ }^{7}$ Such a relationship between an arbitrator and the parties involved, includes that the arbitrator is not subordinate to either party of the dispute or expects any sort of benefit or interest with either parties of the arbitration, or being a stakeholder in connection with the given dispute as the party's attorneys, representatives, employee, witnesses, or expert employed to give their opinions on a related issue.

${ }^{8}$ It is enough for a party challenging an arbitrator to illustrate that there is enough doubt as to that arbitrator's independence or impartiality. Such a formula is easier than actually proving that such an arbitrator lacks impartiality or independence. The formula entails proving the existence of risks or possibilities of lacking partiality or independence, as opposed to a party challenging an arbitrator to establish that the arbitrator lacks independence or impartiality. See, Born, G., International Commercial Arbitration (The Netherlands, Kluwer Law International, 2009), pp. 1474-1475.

${ }^{9}$ Wali, Fathi (2007). Arbitration Law. $2^{\text {nd }}$ Edition. Alexandria: Al Ma'arifInc. P. 245; Abdul-Rahman, Huda M. (1997). Arbitrator's Role in Disputes. Cairo: Al Nahdah Al Arabiyya House. p. 160; Al-Dabbas, Nour (2011). The Legal Organization of Arbitrator Appointment, Challenge and Discharge Proceedings in Light of the Jordanian Law. Unpublished Ph.D. Thesis. p. 85.
} 
expressly approved by the parties of the dispute prior to the proceedings. Such powers may entail that a tribunal is not obliged to adhere to specific procedures or deadlines. In such an event, the arbitrator may give a party a deadline for defense that reasonably goes beyond the common extent of deadlines; while the arbitrator is strict in giving the same extension to other party. The arbitrator may also approve either party's request of expertise on a certain stage of the dispute while declining the same request for the other party at the same stage, even if the latter's request is justified. Partiality can be also concluded if any member of the tribunal adopts a certain cultural, political or ideological thought containing some aggression to either party's thought or doctrine. Or, the arbitrator has previously been a member of the tribunal on another dispute in favor of either party as the latter has challenged him/her due to a personal conflict directly arising from that dispute. Not siding with either party even if selected by either one of them entails that the arbitrator does not act as an attorney for the party that selected him/her. ${ }^{10}$ The arbitrator is neither entitled to defend nor interfere while the arbitration proceedings in progress for either justifying or explaining any point of view on behalf of the party the arbitrator is selected by.

On the other hand, it is neither a matter of partiality nor of dependence if the arbitrator, in good faith, fails to carry out any of his obligations such as the failure to implement some arbitral proceedings, or pay attention to any of the formalities necessary to be made sure of during the arbitration proceedings. It should be only subject to a party's objection or a request to get the given issue reviewed. ${ }^{11}$ Moreover, an arbitrator's dependence does not arise from a mere professional relationship between either parties of the dispute or one of his employees and an arbitrator. An instance of this would be if a party of the arbitration is an engineer and is in contact with another engineer employed by one of the arbitrators. However, such professional relations should not encounter any aggression or conspiracy; otherwise, the principle of independence in arbitration might be deemed to be have been breached.

The arbitrator must maintain impartiality and independence throughout the arbitral proceedings. Whatever the reasons are thereof, the arbitrator has to avoid directly or indirectly meeting or having any sort of communication with the parties of the dispute by any means before the dispute is settled. In case direct contact has occurred with either party, even in an issue that is not related to the given dispute, the arbitrator must disclose such an incident during the first hearing thereof. If this contact is objected to by the other party of the dispute, it must then immediately cease; otherwise, it is approved as the party already has no doubt in the arbitrator's integrity and uprightness. This approval must be actually considered as a legal confirmation that the arbitral proceedings are still to be valid since the reason behind this disclosure is to avoid any objection afterward on the proceedings by either party of the dispute. ${ }^{12}$

By and large, arbitrators are required to keep themselves out of any emotional effects, whether or not related to the dispute itself. The arbitrator is expected to hear a dispute in a highly objective manner. ${ }^{13}$ The arbitrator is also prohibited from having any social courtesies with the parties of a dispute except for such social situations imposed by the ordinary relationships in the society where the arbitrator lives, such as giving condolences and patient visits. In any case, such courtesies are best to be avoided as they could be deemed to influence impartiality and independence of an arbitrator. Under Model Law, arbitrators' impartiality or independence is highly maintained. Article 12(1), stipulates:

When a person is approached in connection with his possible appointment as an arbitrator, he shall disclose any circumstances likely to give rise to justifiable doubts as to his impartiality or independence. An arbitrator, from the time of his appointment and throughout the arbitral proceedings, shall without delay disclose any such circumstances to the parties unless they have already been informed of them by him.

In accordance to Article 12(1) of the Model Law, the arbitrator has to disclose all circumstances that may go along with his/her arbitral task and give rise to 'justifiable doubts' as to his impartiality or independence. The arbitrator should have special attributes as imposed by the nature of the arbitrator assignment or experience upon which he/she has been selected as an arbitrator. Such professional attributes or ethics include the arbitrator's commitment to impartiality or independence, whatever the dispute is or is going to be.

Notwithstanding this commitment, an arbitrator should also disclose any special conditions peculiar to the given

\footnotetext{
${ }^{10}$ Shany, Yuval, Squaring the Circle? Independent and Impartiality of Party-Appointed Adjudicators in International Legal Proceedings, Loyola Los Angeles International \& Comparative Law Review, 2008 volume 30, pp. 473-475.

${ }^{11}$ Abdul Rahman, Huda M. Ibid. p. 169.

${ }^{12}$ Al Nimer, Abul-Ola, ibid. p. 50.

${ }^{13}$ See Wali, Fathi. ibid. p. 250.
} 
dispute that may have any influence on the arbitration proceedings. It is also necessary that the arbitrator shall, at the first arbitral hearing; submit a declaration that entails impartiality or independence which should be filed in the arbitration file. Such a declaration should be recited in the presence of the parties of the dispute or their attorneys. In the case of a tribunal consisting of more than one arbitrator, each arbitrator; whether selected by the parties of the dispute or otherwise appointed by the competent authority; has to submit a separate disclosure statement to confirm independence and impartiality. It is obvious from Article 12(1) that such disclosure is not limited to a specific stage of the arbitration proceedings. ${ }^{14}$ Article 12 does not actually describe the formal procedure in which disclosures are submitted. However, most arbitration national laws require that a disclosure is submitted by the arbitrator in writing. In this case, it shall be deemed to be a procedure that is obligatorily implemented. Otherwise, an oral disclosure by the arbitrator may be provided instead, given that it is recorded as part of the arbitral minutes.

The Model Law does not does not provide non-parties of an arbitration the right to apply for a challenge of an arbitrator for lacking impartiality or independence. Article 13(2) clearly stated: '[...] a party who intends to challenge an arbitrator shall, within fifteen days after becoming aware of the constitution of the arbitral tribunal or after becoming aware of any circumstance referred to in article 12(2), send a written statement of the reasons for the challenge to the arbitral tribunal.' Having said that, a non-party might be directly or indirectly involved in a dispute and such a dispute would affect such a person's status. For example, if the non-party is a subcontractor to one of the arbitration parties, the final award of arbitral tribunal might affect his/her/it status. Indeed if such a person finds that an arbitrator lacks impartiality or independence, he or she should inform the party with whom he or she is directly engaged. However, what if such a party does not take necessary action? One could argue that nothing actually prevents such a third party, after the damage occurs, from directly raising this issue before the competent court/authority, since any arbitral proceeding is not only limited to protecting the rights of arbitration parties, but also aims to protect non-parties of a dispute as well.

In conclusion, this section defined the meaning of arbitrators' impartiality and independence. The notion for challenging the arbitrators' lack of impartiality and independence under the Model Law is the existence of circumstance which is likely to give rise to 'justifiable doubts' rather than actual existence partiality and dependence. Indeed, proving the existence of circumstances which are likely to give rise to 'justifiable doubts', is easier than proving actual partiality or dependence. The effect of such a notion is more noticeable when the challenge is related to impartiality, rather than independence, as the measures for the latter is related to an objective test. The scope of the challenge application for lack of impartiality or independence is not limited to the selecting stage of an arbitrator. It rather relates to the validity of the whole arbitral process. The effects arising from arbitrators' lack of impartiality and independence on the arbitration process is the subject of the following section.

\section{The Effects of a Lack of Impartiality and Independence on Arbitral Proceedings}

It is commonly agreed that the arbitration process in all its stages is based on a set of interrelated proceedings. Hence, a breach at any stage of the arbitration shall affect the whole legal structure of the proceedings. The burden of proof falls on either party who claims the arbitrator lacks impartiality or independence. Either party shall take all the actions determined by the law in applying for the challenge of an arbitrator, as will be described in details in section four of this paper. However, mere doubts are not often substantial enough to directly have an effect on the progress of any arbitral proceedings. In fact, prudence shall be exercised until such doubts are properly justified. Article 12/2 of the Model Law, states:

An arbitrator may be challenged only if circumstances exist that give rise to justifiable doubts as to his impartiality or independence, or if he does not possess qualifications agreed to by the parties. A party may challenge an arbitrator appointed by him, or in whose appointment he has participated, only for reasons of which he becomes aware after the appointment has been made.

With such a loose scope of application as described in Article 12/2, the Model Law has identified the type of procedure to be taken in case of circumstances giving rise to 'justifiable doubts' as to the arbitrator's lack of impartiality or independence.

The Model Law does not mention any specific reasons or grounds for challenging arbitrators. Consequently, one may wonder whether the circumstances, contained in the provision of Article 12/2 as regards the arbitrator's impartiality or independence, can also entail the grounds upon which a judge is challenged, as well as the

\footnotetext{
${ }^{14}$ Sawi, Ahmad S. Al- (2004). Arbitration. $2^{\text {nd }}$ Edition. No Publisher. p. 102; Wali, Fathi (Ibid). p. 262; Murad, Abdul-Fattah (1996). Arbitration Legislation Explained. No Publisher. p. 125.
} 
conditions of a judge's ineligibility on the basis of professional similarities between an arbitrator and a judge. ${ }^{15}$ One could argue however, that although arbitration has a legal nature formally derived from the judicial system, it is based on special regulations and a particular legal framework. The work of an arbitrator shall be different from that of a judge in terms of the effects arising from how available the grounds of challenge and ineligibility for each are. The ineligibility of a judge for hearing lawsuits relates to the public order; its effects arise from the provisions of the applicable law and the judge need not apply for resignation. It rather applies by default. ${ }^{16}$ On the other hand, the arbitrator shall remain eligible as his/her assignment is related to arbitration parties' rights, even if new facts occur after the arbitrator's acceptance of the arbitration assignment that affects his/her impartiality or independence, or the arbitrator's failure to disclose certain facts, believing that such facts should not actually affect his/her impartiality or independence. ${ }^{17}$

Not only does the Model Law have a specific formality when applying for challenging an arbitrator's lack of impartiality or independence, but also there is no specific deadline to apply for a challenge. The challenge may be applied by either party during any of the arbitral proceedings, or even after an award is made on the given dispute. On the other hand, most legal systems have very clear and specific formal procedures and a time limit to challenge a judge. One could therefore argue, that the Model Law should regulate such a matter for the sake of preserving the progress of proceedings and evasion of instability of the tribunal decisions.

With regards to the effect of an arbitrator's impartiality or independence on the proceedings, Article 13 of the Model Law provides:

(1) The parties are free to agree on a procedure for challenging an arbitrator, [...]

(2) Failing such agreement, a party who intends to challenge an arbitrator shall, within fifteen days after becoming aware of the constitution of the arbitral tribunal or after becoming aware of any circumstance referred to in article 12(2), send a written statement of the reasons for the challenge to the arbitral tribunal. Unless the challenged arbitrator withdraws from his office or the other party agrees to the challenge, the arbitral tribunal shall decide on the challenge

(3) If a challenge under any procedure agreed upon by the parties or under the procedure of paragraph (2) of this article is not successful, the challenging party may request, within thirty days after having received notice of the decision rejecting the challenge, the court or other authority specified in article 6 to decide on the challenge, which decision shall be subject to no appeal; while such a request is pending, the arbitral tribunal, including the challenged arbitrator, may continue the arbitral proceedings and make an award.

Indeed if parties agree on the procedures for a challenge application, it should be the document that regulates such a matter. This is the case in either ad hoc or institutional arbitration. Certain arbitration centers have their own procedures to regulate such matters. ${ }^{18}$

Another question that might arise is whether either party of the dispute applies for the challenge of an arbitrator and the tribunal carries on looking at the dispute and finally reaches a judgment before the challenge application is settled by the competent authority. The Model Law does not implement a time limit for settling a challenge. Could the challenge application apply for setting aside the award on the basis that an arbitrator might be lacking impartiality or independence? Article 34 of the Model Law specifies the grounds for setting aside an arbitral award. In fact, there are two possible grounds for setting aside an arbitral award that could be applicable to this scenario. The first could be found in Article 34/2/a/(iv) of the Model Law which states that if the applicant of a challenge furnishes a proof that 'the composition of the arbitral tribunal or the arbitral procedure was not in accordance with the agreement of the parties, unless such an agreement was in conflict with a provision of this Law from which the parties cannot derogate, or, failing such agreement, was not in accordance with this Law'. The other ground could be found in Article 34/2/b/(ii) of the Model Law which states that the court may set the

\footnotetext{
${ }^{15}$ Henry Gabriel Anjanette H. Raymond, Ethics for Commercial Arbitrators: Basic Principles and Emerging Standards, Wyoming Law Review, 2017, vol. 5 (2), pp. 453-455

${ }^{16}$ Zu'bi, Awadh Al- \& Mansour, Anis (2011). The Applicability of Judge Challenge Provisions to Experts in Jordan's Civil Trial Principles Act. Jordanian Journal of Law and Political Science, 3(1). P. 179; Dabbas, Nour A. (Ibid). P. 134; Abul-Wafa, Ahmad (2001). Optional and Obligatory Arbitration. Cairo: Al Ma'arif Inc. P. 381.

${ }_{17}$ Wali, Fathi (Ibid). P. 262; Dasouqi, A. (1995). International and Domestic Commercial Arbitration. Cairo: Madbouli Bookstore. P. 142; Abul-Rahman, Huda M. (Ibid). P. 169; Sawi, Ahmad S. (Ibid). P. 98.

${ }^{18}$ The parties may agree on following the procedures of a given arbitration center with no need for selecting this center to settle the dispute between them. For further details, refer to Haddad, Hamzah A. (2010). Arbitration in Arab Laws. Amman, Jordan: Al Thaqafah House for Publishing and Distribution. P. 131.
} 
award aside if 'the award is in conflict with the public policy...' If this is the case, the question is whether the applications will be individually or collectively looked into by the same concerned authority. ${ }^{19}$ Indeed, setting aside the award in such a scenario is conditional to finding an arbitrator partial or dependent. If an arbitrator is to be found lacking impartiality or independence, all and any arbitral proceedings he/she has taken part in shall consequently be invalid.

Article 34/4 of the Model Law however allows the court, if asked, to suspend setting aside proceeding in order to allow the tribunal to eliminate grounds for setting aside the proceedings. In such a case, if the court finds that the arbitrator lacks impartiality or independence, it may order a reconstruction of the tribunal to eliminate grounds for setting aside the proceedings, then allow time for the reconstructed tribunal to resume its work.

Another related issue might also come into view if either party applies for the challenge of an arbitrator for lacking impartiality or independence or an award is made by the arbitral tribunal before the competent authority settles that challenge application. Given that the execution of an arbitral award entails that it is impossible to restore things to a previous condition, what action shall be taken if this award is made in favor of and executed by the other party, while the party applying for the challenge does not apply for recourse, and the arbitrator is finally challenged?

In line with the Model Law, the effect arising from the challenge of an arbitrator is not expressly stated. Such an effect is left to the parties to agree upon or to the arbitral center (institution) or its proceedings. However, in case of ad hoc arbitration, if the parties fail to regulate the procedure and effects of a challenge application and both the rules of justice and the arbitral system's requirements apply, all the proceedings that the challenged arbitrator has taken part in shall be deemed invalid. This invalidity also applies to the arbitral award to be made by one or more arbitrators and, accordingly, all that has been executed on the basis of this award shall be also void. The executing party shall be responsible for restoring things to the conditions prior to the award; otherwise, by lodging a lawsuit, the party having applied for the challenge, may challenge the arbitral award itself.

Therefore, in response to the questions above, some aspects of a breach that might impede the arbitral proceedings can be identified. Certain periods of time shall be specified for the concerned authority to urgently hear a party's challenge application, taking into account the term of arbitration agreed upon by the parties. Settling this application shall start before the term of arbitration comes to an end; the matter which facilitates the progress of several actions the tribunal may be carried out if it is finally decided to challenge an arbitrator. Most importantly, an arbitral award is not to be made so as to avoid any effects that might be hard to address thereafter.

In all cases, the tribunal may carry on the proceedings until the challenge application is settled, that is pursuant of Article 13/3 of the Model Law, which states: '[...] while such a request is pending, the arbitral tribunal, including the challenged arbitrator, may continue the arbitral proceedings and make an award.' The permissibility intended by this provision entails an option for the tribunal, only on its own discretion, to reasonably decide discontinuing the proceedings. To consult the parties is also permitted as the case so requires. ${ }^{20}$ Yet, the arbitral tribunal shall solely come to a decision in this particular respect based on the conditions of the dispute being heard by it, and also serve a notice of the competent authority looking into the challenge application. ${ }^{21}$

A further question related to this issue is, whether the period of time during which the arbitral proceedings cease until the challenge application is settled by the competent authority, be counted as part of the initial agreed period of the arbitration. In actual fact, the Model Law does not dwell on such a matter. It is left entirely to national legislation or to the agreement of the arbitration parties in their document of proceedings, which may also specify a term of arbitration in harmony with all and any applicable rules and provisions of the governing jurisdiction chosen for the dispute. ${ }^{22}$ By and large, the tribunal shall not wait for the settlement of a challenge application. If the tribunal decides however to cease the proceedings, it shall describe circumstances giving rise

\footnotetext{
19 Dasouqi, A. (1995). International and Domestic Commercial Arbitration. Cairo: Madbouli Bookstore. P. 142; Sawi, Ahmad (Ibid). P. 102; Abul-Wafa, Ahmad (Ibid). P. 381; Tahyawi, M. Al- (2006). Arbitration in Civil and Commercial Acts. Alexandria: University Publications House. P. 209.

${ }^{20}$ Another opinion in jurisprudence, however, says that an agreement shall be held with the parties on this kind of decision since to cease the arbitral proceedings in this respect is not of the same effect as a challenge application. See, Wali, Fathi (Ibid). P. 262.

${ }^{21}$ See, Haddad, Hamzah (Ibid). P. 263.

${ }^{22}$ Article 19 of the Model Law states: '1- Subject to the provisions of this Law, the parties are free to agree on the procedure to be followed by the arbitral tribunal in conducting the proceedings. 2- Failing such agreement, the arbitral tribunal may, subject to the provisions of this Law, conduct the arbitration in such manner as it considers appropriate.'
} 
to this decision and notify the competent authority accordingly. In this respect, what applies to ad hoc arbitration also applies to institutional arbitration. If the arbitration center does not regulate how to cease the proceedings of a dispute, the arbitral tribunal in agreement with the parties may discontinue such proceedings until the challenge application is settled.

Arbitration institutions have different regulations, rules and mechanisms that apply in relation to a challenge application on the proceedings. ${ }^{23}$ For instance, Article 14/3 of the International Chamber of Commerce (ICC) states $^{24}$ :

The Court shall decide on the admissibility and, at the same time, if necessary, on the merits of a challenge after the Secretariat has afforded an opportunity for the arbitrator concerned, the other party or parties and any other members of the arbitral tribunal to comment in writing within a suitable period of time. Such comments shall be communicated to the parties and to the arbitrators.

However, such rules do not regulate the arbitral proceedings at the time that the challenge of an arbitrator is heard by the ICC Court. Principally, the arbitral proceedings of a dispute shall continue while the challenge application is being heard. As the Court is part of the ICC, it shall coordinate and smoothly communicate with the arbitral tribunal hearing the dispute. This particular feature might not be available in case of ad hoc arbitration as a challenge application shall be subject to a competent authority in the country where the dispute arises.

In conclusion, an application to challenge the arbitrator for lacking impartiality or independence shall not affect the progress of proceedings. However, this rule is not absolute, and the arbitral tribunal as part of its ethical conduct, whether consisting of one or more arbitrators, shall decide whenever it is necessary to apply what the tribunal finds serious, unavoidable reasons to challenge the arbitrator. The arbitral proceedings shall eventually cease, with no need therein to wait for the settlement of the challenge application.

\section{The Effect of a Lack of Impartiality and Independence on an Arbitral Tribunal}

The effect arising from either party's application challenging an arbitrator for lacking impartiality or independence, whether or not this challenge is justified, is not limited to the proceedings as concluded in the previous section. It also extends to the arbitral tribunal itself, i.e. whether it consists of one or more arbitrators. The same also applies to both ad hoc and institutional arbitration. The nature of this effect differs in accordance to the physical and emotional status of the arbitrator. The arbitrator's ethical and professional nature is by some means comparable to the judge's job. The question that arises is whether the challenged arbitrator feels embarrassed and, then resigns, or carries on with the assignment at hand. In point of fact, Article 14/2 of the Model Law provides that if: '[...] an arbitrator withdraws from his office [...], this does not imply the acceptance of the validity of any grounds referred to'. Hence, it is obvious that the challenged arbitrator whenever feeling embarrassed; even if he/she is eligible for hearing the dispute; may choose to resign. However, such an arbitrator shall not be then deemed to be lacking impartiality and/or independent. Resignation is also an option for the arbitrator if he/she has certain doubts regarding his/her own impartiality or independence. Without prejudice to either party of the dispute, the cases of embarrassment is discretionary to the arbitrator and should be left to his/her own personal judgment. ${ }^{25}$

The mechanism of resignation whenever the arbitrator is willing to resign due to a challenge application, undertakes to inform the chairman of the tribunal; in case it consists of more than one arbitrator. The competent authority shall be otherwise notified. If any ground of challenge is encountered to apply to the arbitrator, the chairman or the competent authority shall give him/her a permission to resign. However, if he/she only feels embarrassed, the chairman of the arbitral tribunal or the competent authority shall decide to approve the arbitrator's request to resign. Contrary to the reasons of embarrassment, the grounds of challenge are duly stated and determined by the law and shall not be subject to the arbitrator's own discretion. ${ }^{26}$

In case a challenge is applied for and the arbitrator does not resign, the competent authority to which this

\footnotetext{
${ }^{23}$ International Chamber of Commerce (ICC) (2011). Rules of Arbitration and Amicable Settlement of Disputes. $2^{\text {nd }}$ Edition. Paris, France. P. 24.

${ }^{24}$ In the same respect, the Gulf Countries Council Commercial Arbitration Centre (GCCCAC) as per its list of arbitral proceedings is found to give a period of three days from the date on which a challenge is applied for. In accordance with Article 18/2 of its regulation, 'the Secretary-General shall settle a challenge within three days from the date on which it is applied for.'

${ }^{25}$ Zu'bi, Awadh\& Mansour, Anis (Ibid). P. 192.

${ }^{26} \mathrm{Zu}$ 'bi, Awadh \& Mansour, Anis (Ibid). P. 194.
} 
application is submitted shall hear the arbitrator's defense, especially if such a challenge affects the arbitrator's reputation. In actual fact, the arbitrator cannot be considered as an opponent to the party applying for the challenge or the arbitration center that he or she was basically selected by. The decision to challenge the arbitrator shall not affect the validity of the arbitration agreement thereto. What shall be invalidated is the proceedings that the challenged arbitrator has taken part in. ${ }^{27}$ This action shall differ if the challenged arbitrator is unanimously nominated by the parties of the dispute in the arbitration agreement entered between them in case of a single arbitrator. However, if the arbitrator is nominated and approved by the parties as a member of the arbitral tribunal, the aforesaid agreement shall be referred to.

On another related issue, the challenge of an arbitrator for lacking impartiality or independence can affect the constitution of the arbitral tribunal. The challenged arbitrator might have helped select a third arbitrator in case the arbitral tribunal consists of more than one, which is often the method applied in ad hoc types of arbitration. In this respect, Article 11/3/a of the Model Law states: 'in an arbitration with three arbitrators, each party shall appoint one arbitrator, and the two arbitrators thus appointed shall appoint the third arbitrator'. All the proceedings that the challenged arbitrator has taken part in shall be deemed void, including his collaboration with another arbitrator to select a third arbitrator. The task of both the challenged arbitrator and third arbitrator as the challenged arbitrator played part in choosing shall be invalid. However, the third arbitrator may be reselected if the same proceedings are repeated and nothing may then affect his/her being impartiality or independence.

If the challenged arbitrator is the third one, being challenged shall not include the other two arbitrators who have selected him/her. However, they will not be able to carry on with their task since the arbitral proceedings of which this third arbitrator has been a part of, are therein invalid. This particular arrangement requires that the proceedings including the selection of a substitute arbitrator are repeated in accordance with the provision of Article 15 of the Model Law. Based on this Article, the challenged arbitrator shall be substituted in the same way that they are basically selected; if they have not been nominated in the arbitration agreement. In this case, if the challenged arbitrator is selected by either party of the dispute, he/she shall select a substitute arbitrator to start the same proceedings including but not limited to disclosure in coordination with the other arbitrator. Moreover, if the concerned party abstains from nominating another arbitrator, the competent authority shall appoint the new arbitrator. If, however, the arbitrator is selected by the other arbitrators, they then must select a third one. Thirdly, if the challenged arbitrator was appointed by an authority, the party having applied for the challenge may request such an authority to appoint an arbitrator.

As for the direct effect arising from challenging an arbitrator for lacking impartiality or independence in a tribunal, principally all the proceedings that such an arbitrator participated in shall be considered void. However, if the arbitration has continued over a long period of time and reached an advanced stage, will the reconstituted arbitral tribunal; as including the substitute arbitrator, for not wasting time and effort; have an agreement with the parties on keeping some of the proceedings the challenged arbitrator has taken part in.

Principally, revoking proceedings the challenged arbitrator has taken part in, is certainly in the applying party's interests. Due to the flexible, consensual nature of arbitration, the parties' agreement with the arbitrator(s) on considering some of the proceedings as valid, shall depend on the type of the given proceedings. If the challenged arbitrator has not given an opinion on the matter, the dispute cannot be materially affected by a decision that the challenged arbitrator has taken part in making, as he/she had an influence in forming such a matter. ${ }^{28}$ Proceedings may be approved by the reconstituted tribunal in agreement with the parties, provided that no substantial changes occur due to the long time spent or much effort exerted in having arbitrated the given dispute. $^{29}$

Furthermore, an issue that might arise is related to the unchallenged arbitrator's formed opinions in relation to the dispute, especially when the challenged arbitrator has had no role in selecting them, and the effects of these opinions on a new arbitrator's opinion. Principally, if this point of fact is almost imposed by the arbitral proceedings and the nature of the arbitrator's work (unless the parties agree otherwise in their arbitration agreement or terms of reference), all the prior proceedings to be looked into before the presence of the new arbitrator shall be repeated and may be deemed null and void, irrespective of the opinions or thoughts of the

\footnotetext{
${ }^{27}$ Haddad, Hamzah (Ibid). P. 264; Wali, Fathi (Ibid). P. 266; Abdul-Rahman, Huda (Ibid). P. 190; Dabbas, Anwar (Ibid). P. 195.

${ }^{28}$ Fazairi, Amal Al- (without a year of publication). Role of Public Judiciary System in Effective Arbitration. Alexandria, Egypt: Al Ma'arifInc. P. 6; Nimer, Abul-Ola \& Jadawi, A. Q. (without a year of publication). Arbitrators: Special Lessons for Higher Diploma Students. Cairo: Ain Shams University. P. 48.

${ }^{29}$ For instance, if this procedure is an urgent disclosure of a given fact therein, such as if a building is dilapidated or a witness who is ill is to be heard and it has become difficult to rehear him/her especially if his/her statement affects the course in the dispute settled.
} 
former arbitrators. However, a given proceeding may be formally approved and recorded in the minutes as this may help in saving time and effort.

In practice the effect arising from the challenge of an arbitrator in an arbitration center shall be subject to a number of perspectives. If the action taken by the given center is to refer this issue to the national jurisdiction of a country, such arbitration law shall apply. However, the center possibly has certain rules that embark upon a regulation to be the one chosen by the parties to apply to their dispute. For instance, the rules of arbitration and alternative settlement adopted by the ICC have regulated this matter under Article 15/4. Based on this Article, it is obvious that the ICC Rules firstly address the replacement of an arbitrator in case of a challenge. The ICC Court is thereby free to repeat or revoke the arbitral proceedings in case that the challenged arbitrator is reselected. In this respect, the parties may agree on either selecting the ICC for hearing their dispute or only following its procedures and regulations. In the first case, the ICC often has a list of accredited arbitrators and, hence, can appoint one of them in place of the challenged arbitrator. However, in the other case, its procedures shall vary according to what principles the parties of the dispute adopt in selecting the arbitrators.

In actual fact, the ICC Court has its own discretionary power in such cases. The ICC Court normally leaves it to the arbitral tribunal to decide on ruling out the former proceeding entirely or in part. This is because repeating the prior proceeding is a sensitive matter to the arbitral parties. The new arbitral tribunal is then free to call the parties of the dispute so as to assess whether all or any of the prior proceedings the challenged arbitrator has taken part in are essential and can, therefore, be approved. However, the disapproved proceedings by the new arbitral tribunal in agreement with the arbitral parties shall be repeated. The latter is definitely the case with respect to both ad hoc and institutional arbitration. ${ }^{30}$

The justification for repeating the prior proceedings in whole or in part; as demonstrated above in institutional arbitration; is that it goes with the nature of the arbitration or agreement and may be to the mutual benefit of the arbitration parties. ${ }^{31}$ In fact, hearing a dispute by an ad hoc arbitration is possibly different as they might be following a country's relevant legislation. A country's legislation or the parties' agreement, if it includes such issues, shall be particularly adhered to. ${ }^{32}$ One may ask whether either party is permitted to apply for the challenge of more than one arbitrator at the same time. Obviously, this is possible. ${ }^{33}$ The Model Law does not describe the notice to the arbitrator(s) to be challenged and to whom it should be addressed. Contrary to the norms however, it is common practice to address such notice to the arbitral tribunal itself.

\section{Conclusion}

Having investigated the effect of an arbitrator's lack of impartiality or independence on arbitral proceedings, this paper is specifically based on the provisions of Model Law as it is a source or reference to many national arbitration legislations. Special rules and principles are found to individually or collectively regulate the application of challenging the arbitrators' lack of impartiality or independence. It is not easy to distinguish between impartiality and independence in real circumstances. In particular, the lack independence while hearing a dispute is still easier to be demonstrated. An arbitrator's independence is based on an objective test which almost always leads to arbitrator impartiality. The latter however is based on a subjective test. Moreover, independence may obviously be affected by the type of relationship between the arbitrator and either party of the dispute, or those whom the party is directly or indirectly related to. The Model Law should have clearer guidelines to regulate impartiality or independence. This could in turn result in clearer national legislation following the footsteps of the Model Law. The Model Law should also look at issues other than impartiality or independence in which an arbitrator could be challenged.

The challenge of an arbitrator for lacking impartiality or independence significantly affects the arbitral proceedings. A challenge is neither subject to any formal defenses nor to any limits of time; it may be applied for by either party of the dispute at any stage of the arbitration proceedings, or even after an arbitral award for being partial or dependent. The Model Law should adopt a time frame for challenging arbitrators that does not extend until after the award is being made.

Proving partiality or dependence is a factual matter that could be proven by all means of evidence. Applying for a challenge shall be only restricted to the parties of the disputes; no third parties should be directly entitled to apply for it even if an interest of theirs is affected. Model Law should allow both parties who have interests in

\footnotetext{
${ }^{30}$ Haddad, Hamzah (Ibid). P. 266.

${ }^{31}$ See, Haddad, Hamzah (Ibid); Wali, Fathi (Ibid). P. 266; Abdul-Rahman, Huda (Ibid). P. 190; Dabbas, Nour A. (Ibid). P. 173.

32 See, Haddad, Hamzah (Ibid). P. 269; Dasouqi, A. (Ibid). P. 151.

${ }^{33}$ See, Wali, Fathi (Ibid). P. 259; Dabbas, Nour A. (Ibid). P. 160.
} 
the dispute and the other members of the tribunal to challenge an arbitrator on the grounds of lacking impartiality or independence.

The rules adopted by the arbitration institution that the parties have agreed to for settling their dispute shall be adhered to. They are never expected to violate any such rules, including the actions to be taken in case an arbitrator is challenged. As a matter of fact, to challenge an arbitrator for lack of impartiality or independence is not an issue to be subject to public order; its effects are associated with the private interests of either party of the dispute and cannot arise unless a challenge is applied for. The competent authority in charge of deciding whether to discontinue the arbitral proceedings of a dispute or not have discretionary power to look into the seriousness and soundness of grounds for challenging arbitrators is based on lack of impartiality or independence.

Encountering a lack of impartiality or independence, the arbitrator may choose to resign before being challenged before the competent authority as the national jurisdiction of a country so requires. However, if the arbitrator feels uncomfortable to continue carrying out the assignment due to a party challenging his/her impartiality or independence, the tribunal's chairman or the competent authority shall then decide on the matter. This, however, does not mean that the resigned arbitrator acknowledges lack of impartiality or independence. A challenge to an arbitrator's impartiality or independence could indeed be withdrawn in the case that the arbitrator chooses to resign or the given party finds no real grounds for the challenge.

In all circumstances, a decision against an arbitrator's impartiality or independence does not affect the validity of the arbitration agreement itself. The arbitration agreement shall remain valid and legally binding. What shall be eventually void is only the arbitral proceedings in which the challenged arbitrator has taken part in. 